\title{
PERANAN PENGAWAS SEKOLAH DALAM MENINGKATKAN KOMPETENSI MANAJERIAL KEPALA MADRASAH STUDI KASUS DI MI WIDADA KABUPATEN BLITAR
}

\author{
ULFATUR ROSYIDAH \\ Pengawas Madrasah Kementerian Agama Kab. Blitar \\ Email: bagusulfa768@gmail.com
}

\begin{abstract}
ABSTRAK
Penelitian ini bertujuan untuk mendiskripsikan tentang peranan pengawas sekolah dalam meningkatkan kompetensi manajerial kepala sekolah (Studi Kasus di Madrasah Ibtidaiyah Widada Kabupaten Blitar). Metode penelitian menggunakan pendekatan kualitatif dengan rancangan studi kasus dengan analisis data model interaktif, metode pengumpulan data menggunakan observasi, wawancara mendalam, dan dokumentasi. Dari hasil penelitian menyimpulkan bahwa: 1) Pengawas melakukan pembinaaan kualitas kompetensi manajerial kepala madrasah secara terencana dan berkelanjutan, 2) Pengawas memberikan pembinaan kualitas kompetensi manejerial hubungan masyarakat, dan 3) Pengawas memberikan pembinaan kepada kepala madrasah dan guru untuk meningkatkan integritas dan profesional dalam melaksanakan tugas fungsinya. Sedangkan rekomendasi dari penelitian ini, antara lain, yaitu: 1) Kepala madrasah secara terus agar meningkatkan kompetensi manajerialnya dalam mengelola semua sumberdaya untuk memberikan layanan pendidikan yang berkualitas kepada masyarakat, (2) Kepala sekolah harus menjadi sosok tauladan tidak hanya bagi guru, juga kepada warga sekolah dan masyarakat, (3) Kepala Madrasah harus memiliki integritas yang tinggi dan profesional dalam menjalankan tugasnya.
\end{abstract}

Kata Kunci: Pengawas sekolah, Kepala sekolah, Manajerial Kepala sekolah

\section{PENDAHULUAN}

Lembaga pendidikan adalah pusat lahirnya sumber daya manusia yang unggul di masa mendatang. Melalui pendidikan generasi muda Indonesia dapat berekplorasi memupuk mental dan memiliki daya saing tinggi. Setiap lembaga pendidikan berkewajiban untuk bisa mencapai visi, misi \& tujuan yang telah dirumuskanya. Dalam mewujudkannya tidak lepas dari kemampuan kepala sekolah itu sendiri, dalam hal ini adalah kepala sekolah harus memiliki kompetensi manajerial sebagai kunci dari pada kemajuan lembaga pendidikan. Kepala sekolah yang peneliti maksud disini adalah kepala Madrasah Ibtidaiyah (MI). Kompetensi manajerial kepala madrasah adalah proses pengelolaan dari kepala Madrasah dengan melakukan perencanaan, mengelola, mendayagunakan, menciptakan, dan mengontrol kegiatan yang ada di sekolah/ madrasah secara efektif dan efisien. Suatu pengelolaan sekolah/ madrasah yang baik dengan peranan kepala madrasah yang maksimal dan bertanggung jawab akan berdampak terhadap sekolah/ madrasah akan terjamin kualitas pendidikan berstandar nasional (Kusuma, dkk. 2020). Oleh karena itu, maka kepala madrasah dituntut untuk memiliki kompetensi manajerial yang tinggi agar mampu mengambil keputusan dan inisiatif/ prakarsa untuk meningkatkan kualitas pendidikan madrasah. Asmendri, (2018) mengatakan bahwa, secara umum kompetensi manajerial kepala madrasah yang diteliti tergolong baik pada semua aspek, yaitu terdiri dari aspek perencanaan kegiatan madrasah, pengorganisasian kegiatan, menggerakkan, dan pengendalian aktifitas (Imron, at all. 2021).

Hal ini jelas menunjukkan bahwa kepala madrasah haruslah memiliki kompetensi yang tidak hanya sebatas kecakapan interaksi, melainkan harus memiliki kompetensi yang merupakan prilaku yang rasional untuk mencapai tujuan persyaratan sesuai dengan kondisi yang diharapkan hingga sesuai dengan standar kepala sekolah/ madrasah yang diatur dalam Peraturan Menteri Pendidikan Nasional Nomor 13 Tahun 2007, menyebutkan bahwa ada lima kompetensi yang harus dimiliki oleh kepala madrasah yaitu kompetensi; kepribadian, manajerial, supervisi, kewirausahaan, \& sosial (Menteri Pendidikan Nasional, 2007). 
Nursaid (2020) mengungkapkan bahwa, kualitas pendidikan madrasah bergantung pada banyak faktor seperti kepemimpinan kepala madrasah dan faktor pendukung lainya yang berperan penting dalam menjaga dan menjamin kualitas pendidikan madrasah, (Imron, at all. 2021). Hal ini menunjukkan bahwa meskipun peran dan tanggung jawab kepala madrasah sangat berdampak terhadap keberhasilan dan kualitas pendidikan madrasah, namun ada faktor lain yang berperan penting di madrasah juga sangat berpengaruh kepada keberhasilan dan kualitas pendidikan madrasah, seperti tidak disiplin guru menjadi sorotan warga lingkungan masyrakat. Hal ini sudah otomatis mengurangi kepercayaan masyarakat terhadap hasil pendidikan madrasah yang tentunya pada perekrutan pesera didik. Mulyasa (2007) menjelaskan guru sebagai pendidik adalah yang menjadi tokoh, panutan, dan identifikasi bagi para peserta didik, dan lingkunganya (Wijaya, 2021). Hal ini menunjukkan bahwa untuk menjadi seorang guru harus bisa mencerminkan kepribadian yang positif yaitu disiplin, supel, sabar, jujur, rendah hati, berwibawa, santun, empati, ihlas, berakhlak mulia, bertindak sesuai norma sosial dan hukum, dll. Kepribadian seorang guru terebut akan bisa dan mudah dimiliki semua guru, apabila kepala sekolahnya juga memiliki kompetensi kepribadian yang positif yaitu berakhlak mulia, berintegritas yang kuat sebagai pemimpin dan komitmen, peraturan perusahaan dan norma-norma sosial yang berlaku (Wijaya, ad, all 2021). Hal ini dikandung maksud bahwa kepala madrasah merupakan tauladan bagi pendidik dan tenaga kependidikan, termasuk tauladan kedisiplinan. Agar kompetensi manajerial kepala madrasah benar-benar bisa dimilikinya dengan maksimal, maka sangat dibutuhkan peranan pengawas sekolah/ madrasah sebagai upaya untuk mendorong kepala madrasah dalam melaksanakan tugas pokok dan fungsinya sebagai pemimpin. Pengawas yang peneliti maksud disini adalah pengawas madrasah.

Analisa ini mengindikasikan tiga aspek penting bagi pengawas madrasah dalam pengembangan profesinya, atau bisa dikatakan 3 peranan penting pengawas madrasah adalah (1) sebagaai supervisor, (2) sebagai motivator dan (3) sebagai evaluator (https//gtk. Kemendikbud.go.oid). (Ketiga peranan pengawas tersebut merupakan faktor penting yang tidak bisa dipisahkan satu sama lainya bagi kepala madrasah serta menjadi tanggung jawab pengawas madrasah dalam memperbaiki kinerja kepala madrasah. Peran pengawas sebagai "Supervisor", baik akademik maupun manajerial. Supervisor akademik adalah pengawas berkewajiban untuk membantu kemampuan guru agar guru dapat meningkatkan mutu proses pembelajaran. Supervisor manajerial adalah pengawas berkewajiban untuk membantu kepala madrasah dalam meningkatkan kompetensi manajerialnya.

Peran pengawas sebagai motivator adalah pengawas berkewajiban memotivasi kepala madrasah dalam melaksanakan tupoksi kepala madrasah. Peran pengawas sebagai evaluator adalah pengawas berkewajiban menilai kinerja kepala madrasah, yang disebut dengan PKKM (Penilaian Kinerja Kepala Madrasah), dengan mengacu kepada Peratuan Menteri PAN \& RB Nomor 21 Tahun 2010 pasal 5 berbunyi Tugas Pokok pengawas madrasah adalah melaksanakan tugas pengawasan akademik dan manajerial pada satuan pendidikan yang meliputi penyusunan program pengawasan, pelaksanaan pembinaan, pemantauan pelaksanaan 8 Standar Nasional (MENPANRB, 2010).

Adapun untuk mewujudkan peranan pengawas dalam meningkatkan kompetensi manajerial kepala madrasah adalah dengan melaksanakan tugas pokok tersebut yang menjadi tanggung jawabnya. Terkait hal tersebut, maka seorang pengawas dituntut memiliki kompetensi pengawasan akademik yakni menilai guru dalam rangka mempertinggi kualitas proses pembelajaran yang dilaksanakannya, agar berdampak terhadap kualitas hasil belajar siswa, dituntut pula memiliki kompetensi pengawasan manajerial yang pada dasarnya berfungsi sebagai pembinaan, pembimbingan dan penilaian kepala madrasah dalam pengelolaan lembaga binaanya, untuk meningkatkan kinerja kepala madrasah, tenaga kependidikan lainya. Hal ini menunjukkan bahwa keberadaan peranan pengawas madrasah adalah merupakan figur utama bagi kepala madrasah dalam proses mencapai visi misi \& tujuan yang telah dirumuskan, disamping dalam proses pelaksanaan pengelolaan lembaga pendidikan yang menjadi tugas dan 
tanggung jawab serta wewenang secara penuh untuk melakukan penilaian dan pembinaan kepada guru dari segi teknis pendidikan dan administrasi. Melihat tugas dan tanggung jawab serta wewenang kepala madrasah yang relevan dengan tugas pokok pengawas, maka ini menunjukkan bahwa betapa pentingnya peranan pengawas madrasah dalam meningkatkan kompetensi manajerial maupun akademik kepala madrasah dalam proses pengelolaan dan peningkatan mutu pendidikan madrasah.

Berdasarkan latar belakang masalah di atas, Peneliti tertarik melakukan penelitian peranan pengawas madrasah dalam meningkatkan kompetensi manajerial kepala madrasah.

\section{METODE PENELITIAN}

Penelitian ini menggunakan pendekatan kualitatif dengan rancangan studi kasus. Dipilihnya rancangan untuk mengungkapkan secara alami tentang fenomena yang terjadi di Madrasah Ibtidaiyah Widada Kabupaten Blitar. Pengumpulan data penelitian menggunakan metode wawancara, dan dokumentasi. Dalam wawancara peneliti sendiri sebagai instrumen utama (key insrumen) secara langsung kepada informan kunci yaitu Kepala MI, Guru, Siswa dan Wali murid. Sedangkan dokumentasi sebagai pedukung informasi dari hasil wawancara berupa photo, gambar, vidio, dan dokument kegiatan program MI. Desain analisis data kualitatif menggunakan Model Interaktif dari Miles \& Huberman (1984) dapat dilihat pada gambar berikut. Teknik analisis data dalam penelitian menggunakan teknik analisis data model interaktif yang diterangkan oleh (Miles, Huberman, \& Saldana, 2014).

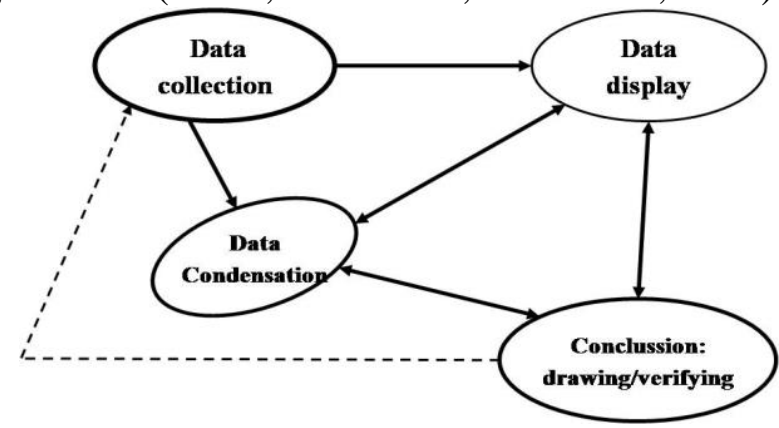

Gambar 1. Analisis data model interactive

(Miles, Huberman, \& Saldana, 2014; Hariawan et al., 2019)

Proses analisis data dimulai dengan menelaah seluruh data yang tersedia dari berbagai sumber, yaitu dari wawancara, pengamatan yang sudah dituliskan dalam catatan lapangan, dokumen pribadi, dokumen resmi, gambar, foto, dan sebagainya (Moleong, 2012; Hariawan \& Faqih, 2016).

\section{HASIL DAN PEMBAHASAN}

1. Kompetensi Manajerial Kepala Sekolah/Madrasah

Hasil penelitian menunjukkan bahwa kompetensi manajerial kepala Madrasah Ibtidaiyah (MI) Widada masuk dalam kategori lemah. Terkait perekutan MI Widada 5 tahun terahir ini sangat memprehatinkan dibanding tahun-tahun sebelumnya. Dimana hasil analisis data dokumen 5 tahun sebelumnya MI Widada pernah mengalami kemajuan yang hebat sebagaimana umumnya sekolah yang ada di wilayah MI Widodo. Analisis data dokumen dan observasi pada 5 tahun terahir ini, MI Widada jumlah murid makin menyusut yaitu dapat di lihat pada kelas $1 \mathrm{~s} / \mathrm{d}$ kelas 6 dengan rata-rata siswa berjumlah 9 s/d 15 orang, dengan guru 4 orang, 2 yang aktif, satu sebagai kepala Madrasah \& yang satu sebagai operator Dapodik/ Emis, 2 orang guru lainnya kurang aktif. Hasil analisis lapangan juga menemukan data 2 tahun terahir ini hanya mendapatkan murid 4 orang saja.

Berdasarkan temuan ini dapat ditarik kesimpulan bahwa kemampuan manajerial kepala Marasah Ibtidaiyah Widada, yaitu: 1) belum sepenuhnya melaksanakan tugas pokoknya secara maksimal; 2) belum mengimplementasikan kompetensi manajerial kepala madrasah yang profesional. 
2. Kompetensi Kepribadian Guru

Berdasarkan hasil analisis data menyimpulkan keadaan bahwa kompetensi kepribadian guru dalam kategori lemah, yang dapat dilihat, antara lain, dari: 1) para guru kurang semangat dalam melaksanakan tugas pokok dan fungsinya sebagai guru terhadap siswa; 2) Guru mengabaikan peraturan disiplin; 3) Hubungan sosial dengan stakeholder atau warga masyarakat belum terealisaikan oleh para guru atau warga madrasah; 3) Terjadinya Mis komunikasi kepala madrasah dengan komite, yayasan; 4) Peran komite madrasah tidak maksimal. Hal ini berarti warga madrasah belum memiliki kompetensi kepribadian yang harus dimiliki oleh seorang guru.

3. Hasil Pendidikan

Hasil penelitian menunjukkan bahwa ketercapaian hasil pendidikan kurang berkualitas, hal ini karena 1) separuh guru berkualifikasi ijazah SMA, 2) keterbatasan anggaran dana, sarana prasarana, \& Jumlah murid serta guru yang sangat minim, sehingga warga madrasah lemah dalam setiap melangkah yang tentunya berefek puruk terhadap keberhasilan pendidikan.

4. Faktor Yang Menghambat Pengawas \& Kepala

Beberapa faktor yang menjadi kendala pengawas \& kepala madrasah dalam melaksanakan tugas pokok dan fungdinya, antara lain; 1) letak geografis MI Widada berada di Kecamatan Pagergunung yang minim penduduknya, 2) Posisi tempat hanya berjarak $1 \mathrm{~km}$ dengan lembaga yayasan kristen yang nampak sudah maju, dengan memiliki 3 jenjang pendidikan yaitu PAUD, SD dan SMP, (3) MIS hubungan sosial warga madrasah dengan warga masyarakat atau stakeholder yang kurang familier.

Terkait dengan kendala oleh pengawas \& kepala madrasah ini, dapat disimpulkan bahwa sangat dibutuhkan peranan pengawas madrasah yang profesional yang mampu mengimplemetasikan peranannya dalam meningkatkan manajerial kepala madrasah.

\section{Pembahasan}

Berdasarkan hasil temuan penelitian tentang peran pengawas sekolah/ madrasah dalam meningkatkan kompetensi manajerial kepala madarasah, sebagaimana yang telah diuraikan di atas, yang meliputi 5 hal, antara lain: 1) Kompetensi Manajerial Kepala Madrasah, 2) Kompetensi Kepribadian Guru, 3) Hasil Pendidikan, 4) Faktor Yang Menghambat Pelaksanaan Tugas Pengawas dan Kepala. Maka sesuai tujuan penelitian, yakni untuk mendiskripsikan peranan pengawas sekolah/ madrasah dalam meningkatkan kompetensi manajerial kepala madrasah, adalah;

1. Kompetensi Manajerial Kepala Madrasah

Berkaitan dengan kompetensi kepala madarasah sebagaimana yang ditemukan dalam penelitian ini termasuk kompetensi manjerial yang lemah, maka peranan pengawas sekolah/ madrasah terhadap kepala madrasah yang lemah pada aspek manajerial adalah "Pelaksanaan Supervisi Manajerial Pengawas Sekolah/ Madrasah”.

Manajerial pada hakekatnya adalah pengelolaan yang dilakukan pengawas sekolah/ madrasah maupun kepala sekolah /madrasah dalam memenejemen lembaga sekolah/ madrasah dan penting untuk dilakukan oleh pengawas sekolah/ madrasah maupun kepala sekolah/ madrasah agar visi, misi dan tujuan pendidikan tercapai dengan maksimal, (Kusuma, Hamengkubuwono, Ifnaldi, Warlisazusi, J. 2020).

Atmodiwiryo dalam sodiqin dan Nurdin (2016) menyatakan kompetensi manajerial adalah seperangkat ketrampilan teknis dalam melaksanakan tugas sebagai menajer sekolah untuk memberdayagunakan segala sumber yang tersedia untuk mencapai tujuan sekolah secara efektifbdan efisian (Imron, at all, 2021). Robbins (2011) mengungkapakan bahwa Kompetensi manajerial kepala madrasah adalah kemampuan dalam melaksanakan fungsi planning (perencanaan), Organisinng (pengorganisasian), leading (kepemimpinan) dan controling (pengendali) pada seluruh sumber daya secara efektif dan evision (Imron, at all, 2021). Wahyudi (2016) dalam Imron, et.al, (2021) menyatakan kompetensi manajerial kepala 
madrasah adalah kemampuan kepala madrasah dalam mengelola sumberdaya organisasi berdasarkan kompetensi yang telah ditetapkan. Dari beberapa pendapat tersebut diantaranya tidak jauh bebeda, hampir sama yang intinya dapat disimpulkan bahwa kompetensi manajerial kepala madrasash adalah kemampuan kepala madrasah dalam mengelola madrasah dengan memberdayagunakan segala sumber yang ada yang mencakup 4 aspek perencanaan, pengorganisasian, kepemimpinan, dan pengendalian untuk mencapai visi, misi,dan tujuan yang telah dirumuskan.

Seiring berkembangnya zaman menuju globalisasi, kepala madrasah dituntut dapat menyesuaikan diri sesuai dengan fungsinya sebagai kepala madrasah yang Profesional. Begitu juga halnya pelajaran K13 lama harus diganti dengan K13 terbaru, untuk pemenuhan kebutuhan dasar peserta didik dalam mengembangkan kemampuanya di era digital. Hal ini sesuai dengan

Peraturan Menteri Pendidikan dan Kebudayaan Nomor 37 Tahun 2018 ini ditetapkan dengan pertimbangan guna memenuhi kebutuhan dasar peserta didik dalam mengembangkan kemampuannya di era digital. Esensinya pendidikan itu hendaknya mampu menambahkan dan mengintegrasikan muatan informatika pada kompetensi dasar. Baik dalam dalam kerangka kurikulum maupun pada struktur kurikulum 2013 mulai dari jenjang pendidikan dasar hingga pendidikan menengah (Permendikbud, 2018)

Berkaitan dengan kompetensi kepala madarasah sebagaimana yang ditemukan dalam penelitian ini termasuk kompetensi manjerial yang lemah, maka peranan pengawas sekolah/ madrasah terhadap kepala sekolah/madrasah yang lemah pada aspek manajerial adalah "Pelaksanaan Supervisi Manajerial Pengawas sekolah/ madrasah "

Di sekolah/madrasah, ada supervisi akademik dan supervisi manajerial yang sama-sama dilakukan pengawas sekolah/ madrasah dan kepala sekolah/madrasah. Supervisi yang dilakukan pengawas madrasah bertujuan untuk membantu warga madrasah yang meliputi; kepala madrasah, guru, dan tenaga kependidikan agar mereka dapat melasanakan tugasnya secara profesional (Depdiknas, 2010; 7). Terkait hal itu, maka pengawas madrasah dituntut bekerja/melaksanakan supervisinya secara profesional juga. Sebagaimana telah diatur dalam Peraturan Menteri Pendidikan Nasional Nomor 12 Tahun 2007 tentang Standar Pengawas Sekolah/Madrasah, menyebutkan bahwa pengawas sekolah/madrasah wajib memiliki kompetensi minimal yaitu kompetensi kepribadian, supervisi manajerial, supervisi akademik, evaluasi pendidikan, penelitian pengembangan dan kompetensi sosial. Berdasarkan peraturan tersebut, pengawas wajib pula mengimplementasikan kompetensi-kompetensi tersebut sehingga terwujud peranan pengawas madrasah dalam meningkatkan kompetensi menejarial kepala madrasah yang profesional, dalam hal ini salah satu diantaranya adalah melakukan supervisi manajerial dengan sasarannya adalah meningkatkan kompetensi manajerial kepala MI Widada melalui peningkatan administrasi tenaga kependidikan atau semua warga madrasah yang berperan penting dalam peningkatan mutu madrasah dan keberhasilan proses pembelajaran.

Dari paparan tujuan, sasaran dan pelaksanaan supervisi manajerial pengawas madrasah terkait dengan hasil temuan, maka peneliti dapat mendiskripsikan peranan pengawas sekolah/ madrasah dalam meningkatkan kompetensi manajerial kepala Madrasah/ MI Widada melalui pelaksanaan supervisi manajerial pengawas madrasah, sebagai berikut: (1) Supervisi manajerial dalam perencanaan perekrutan peserta didik baru. (2) Monitor penerimaan peserta didik baru (PPDB). (3) Supervisi manaejerial dalam perencanaan yang mendukung terlaksananya proses pembelajaran dan peningkatan mutu. (4) Supervisi manajerial dalam pelaksanaan 8 Standar Nasional Pendidikan (SNP), (5) Memantau madrasah, apakah madrasah tersebut bisa mencapai tujuan, visi dan misi apa tidak, apabila tidak selanjutnya dilakukan perbaikan oleh pengawas madrasah.

2. Kompetensi Kepribadian Guru

Berkaitan dengan kompetensi kepribadian guru sebagaimana yang ditemukan dalam penelitian ini termasuk kompetensi kepribadian guru yang lemah, maka peranan pengawas 
sekolah/madrasah terhadap madrasah pada asperk kompetensi kepribadian guru adalah "Pelaksanaan Supervisi Akademik"

Pelaksanaan supervisi akademik dilakukan pengawas bertujuan untuk menilai dan membina guru dalam rangka mempertinggi kualitas proses pembelajaran yang dilaksanakanya, agar berdampak terhadap kualitas hasil belajar siswa (Dirjen PMPTK, 2009). Pelaksanaan supervisi akademik membantu menyelesaikan masalah guru terkait administrasi pembelajaran, agar mereka bisa bekerja secaran profesional. Guru merupakan bagian terpenting disekolah yang sangat berpengaruh terhadap keberhasilan sekolah. Gurulah yang berhadapan langsung dengan siswa dalam proses pembelajaran. Guru juga yang berhadapan langsung dengan stakeholder/warga masyarakat yang memberi kepercayaan atas keberadaan madrasah. Didalam diri guru harus terdapat sikap yang baik sehingga bisa ditiru. Menurut UU No.14 Th. 2005 tentang Guru dan Dosen; bahwa seorang guru harus memiliki empat kompetensi dasar dalam pendidikan, meliputi kompetenai pedagogik, kompetensi profesional, kompetensi kepribadian dan kompetensi sosial. Berdasarkan UU dan paparan tersebut, fakta di lapangan yakni di MI Widada, terkait kompetensi kepribadian guru masih lemah sehingga berdampak negatif pada semua eleman yang ada di MI Widada. Dampak negatif sebagaimana telah peneliti tuliskan di pendahuluan, maka peneliti mendiskripsikan peranan pengawas dalam meningkatkan kompetensi manajerial kaitanya dengan hasil temuan adalah; (1) Pelaksanaan supervisi akademik, (2) Pelaksanaan pembinaan guru terkait hubungan sosial. (3) Pelaksanaan pembinaan guru di Klompok Kerja Guru (KKG) sebagai sarana guru dalam meningkatkan kompetensinya, (4) Pelaksanaan pembinaan guru terkait pendekatan terhadap yayasan, komite, tokoh agama dan lingkugan warga masyarakat sehingga ada perhatian dari komite, Yayasan dan kepercayaan dari warga masyarakat atas keberadaan madrasah.

3. Hasil Pendidikan.

Berkaitan dengan hasil pendidikan MI Widada sebagaimana yang ditemukan dalam penelitian ini termasuk hasil pendidikan yang kurang berkualitas, maka peranan pengawas sekolah/ madrasah adalah "Pelaksanaan Semua Tugas Pokok Pengawas Sekolah/ Madrasah"

Diabad $21 \mathrm{ini}$, tugas pokok pengawas sekolah/madrasah sudah ada pembenahan agar bisa mengikuti perkembangan IPTEK 4.0 yaitu mengacu pada Permendikbud Nomor 143 Tahun 2014, menyebutkan bahwa "Tugas Pokok dan Fungsi Pengawas adalah melaksanakan kepengawasan akademik dan manajerial yang antara lain; (1) Menyusunan Program Pengawasan Tahunan yaitu program tahunan, program semester, instrumen, dan menyusun Rencana Pengawasan Akademik (RPA), Rncana Pengawasan Manajerial (RPK). (2) Pembinaan Guru dan Kepala, (3) Pemantauan 8 SNP, (4) Penilaian Kinerja Guru dan Kepala, (5) Evaluasi Hasil Pelaksanaan Program Pengawasan di madrasah binaan, (6) Menyusun Program Bimbingan Latihan (Bimlat) Profesional Guru, (7) Melaksanakan Bimlat Profesional Guru, (8) Mengevaluasi Hasil Bimlat Guru, (9) Melaksanakan Pengembangan Profesi, (10) Melaksanakan Kegiatan Yang Mendukung Tugas Pokok Pengawas.

Dari beberapa tugas pokok pengawas madrasah tersebut nampak jelas kiprah dan peranan pengawas sekolah/ madrasah menjadi bagian integral dalam peningkatan menejerial kepala madrasah. Hal ini pengawas madrasah harus paham dengan semua tugas tugas tersebut yaitu dalam melaksanakan tugas pokoknya butuh persiapan dan perencanaan yang sesuai dengan apa yang akan pengawas lakukan di lembaga tersebut, sehingga baik kepala maupun guru-guru tidak hanya sekedar memperbaiki laporan saat pengawas berkunjung ke madrasah. Setelah melakukan persiapan dan perencanaan yang sesuai, maka pengawas madrasah harus memahami pula fungsinya sebagai pengawas yakni membina \& membimbing serta mengevaluasi terutama manajerial kepala madrasah dalam mencapai keberhasilan pendidikan sesuai visi misi yang telah dirumuskan sehingga kehadiran pengawas di madrasah benar benar bermanfaat bagi semua warga madrasah. Namun demikian, Fakta di lapangan (di MI Widada), pengawas madrasah belum bisa melaksanakan tugas pokok dan fungsinya dengan maximal atau bisa dikatakan masih mencapai 75\%. Hal ini disebabkan banyak tantangan-tantangan yang menghambat pengawas ataupun kepala madrasah dalam melaksanakan tugas pokok dan 
fungsinya. Selain tantangan dari luar warga madrasah, juga tantangan dari warga madrasah itu sendiri.

4. Faktor Faktor Yang Menghambat

Berkaitan dengan faktor faktor yang menghambat pengawas madrasah maupun kepala madrasah dalam melaksanakan tugas pokok dan fungsinya sebagaimana yang ditemukan dalam penelitian ini termasuk faktor faktor yang menghambat, maka peneliti dapat mendiskripsikan peranan pengawas madrasah dalam meningkatkan manajerial kepala madrasash, adalah "Pelaksanaan upaya pengawas madrasah mengatasi tantangan-tantangan dan membantu menyelesaikan masalahnya, antara lain; (1) Upaya pengawas madrasah mengatasi guru yang kurang aktif, dengan sering dilakukan supervisi akadenik, (2) Upaya pengawas madrasah mengatasi warga madrasah yang kurang disiplin, tidak familier terhadap warga masyarakat dan sebaliknya warga masyarakat yang lebih banyak tidak percaya dengan kualitas dan keberadaan MI Widada, yaitu dengan dilakukan pembinaan-pembinaan warga madrasah MI Widada dan merekrut guru dari warga masyarakat setempat agar warga madrasah lebih cederung bisa menciptakan hubungan yang akrab familier terhadap waga masyarakat (3) Upaya pengawas madrasah bersinergi dengan ketua yayasan untuk merekut komite dari warga masyarakat yang faham dibidang pendidikan dan bersodolidaritas yang tinggi, (4) Upaya pengawas madrasah bersinergi dengan kepala, komite dan ketua yayasan MI Widada, untuk merekut warga masyarakat (Tokoh Agama) untuk menjadi pengurus MI Widada, agar warga madrasah cenderung lebih mudah mengadakan kegiatan kegiatan yang terkait dengan promosi promosi kelebihan dan keberadaan MI Widada.

Agar pengawas madrasah mampu mengatasi \& menyelesaikan berbagai tantangan yang menjadi faktor penghambat tersebut, maka pengawas madrasah harus mampu bekerja sesuai profesionalitas dan mampu mengimplementasikan 6 kompetensi minimal pengawas madrasah; kompetensi kepribadian, kompetensi manajerial, kompetensi akadmik, kompetensi evaluasi pendidikan, kompetensi penelitian dan pengembangan, kompetensi social (Permendiknas, 2007). Dalam Dirjen PMPTK, (2009; Aguslani, 2019) menjelaskannya sebagai berikut.

1) Kompetensi Kepribadian Pengawas adalah kemampuan pengawas berkaitan dengan aspek nilai dan sikap serta motivasi dalam komitmen.Kompetensi ini terdiri dari dua materi, yaitu pengenalan dan mengembangankan diri ,dan memberdayakan diri, serta kreativitas dalam pengambilan keputusan

2) Kompetensi Supervisi Akademik adalah kemampuan pengawas madrasah dalam melaksanakan pengawasan akademik yakni menilai dan membina guru dalam rangka mempertinggi kualitas proses pembelajaran yang dilaksanakanya, agar berdampak terhadap kualitas hasil belajar siswa. Sasaran supervisi akademik adalah guru

3) Kompetensi Manajerial, adalah kemampuan pengawas $\mathrm{S} / \mathrm{M}$ dalam melaksanakan pengawasan manajerial berkenaan dengan aspek pengelolaan $\mathrm{S} / \mathrm{M}$ dalam rangka mencapai keberhasilan pendidikan madrasah. Pengawasan manajerial sasaranya adalah krepala \& staf madrasah.

4) Kompetensi Evaluasi Pendidikan. Adalah kemampuan perngawas S/M dalam melakukan bimbingan guru dan kepala S/M menyusun kriteria dan indikator keberhasilan pembelajaran agar bdapat menjalankan tugas masing

5) Kompetensi Penelitian, adalah kegiatan pengembangan profesi pengawas dalam rangka mencapai pengalaman ilmu teknologi, pengetahuan dan ketrampilan untuk peningkatan mutu, baik bagi mproses belajar mengajar dan profesonalisme tenaga kependidikan lainya.

6) Kompetensi Sosial, adalah kemampuan pengawas berkaitan dengan aspek nilai dan sikap serta motivasi dan komitmen. Materi ini terdiri dari dua materi yaitu mengembangkan kemitraan dan TIM kerja.

Keputusan Menteri Negara Pendayagunaan Aparatur Negara Nomor 118/1996 Pengawas Madrasah adalah pegawai negeri sipil yang diberi tugas, tanggung jawab dan wewenang secara penuh oleh pejabat yang berwenang untuk melakukan pengawasan dengan melaksanakan 
penilaian dan pembiaan dari segi teknis pendidikan dan administrasi pada satuan pendidikan pra sekolah, dasar dan menengah (Departemen Agama RI). Terkait ini maka jelaslah bahwa seorang pengawas madrasah harus berperan aktif melaksanakan tugas pokoknya, dan merealisasikan 6 kompetensi yang dimiliki, terutama kompetensi akademik dan manajerial.

Sahartian menegaskan bahwa pengawasan pendidikan tidak lain dari usaha memberikan layanan kepada stakeholder pendidikan, terutama kepada guru-guru, baik secara individu maupun secara klompok dalam usaha memperbaiki kualitas proses dan hasil pembelajaran (Konsep Pendidikan, 2000).

Berdasarkan 2 difinisi tersebut diatas, maka seorang pengawas harus bertanggung jawab terhadap semua warga madrasah terutama yang menjadi lembaga binaanya, yang didalamnya ada stakeholder pendidikan, guru dan kapala madrasah. Taufik, (2019) mengungkapkan pengawas merupakan mitra kerja kepala sekolah dan guru dalam meningkatkan mutu dan kualitas pendidikan. Pengawas madrasah adalah tenaga kependidikan yang berfungsi untuk menjamin terselenggaranya pendidikan yang profesional di madrasash. Para pengawas tidak secara langsung terlibat dalam proses pendidikan dan pengajaran di madrasah, tetapi mereka berperan dalam menunjang kegiatan pendidikan di madrasah. Guru, kepala sekolah, dan pengawas madrasah, adalah tiga serangkai pelaku pendidikan yang dalam melaksanakan tugas harus bersinergi, saling mendukung guna terlaksananya peran dan fungsi masing-masing (Kasubag perencanaan dan Data Dinas Pendidikan Kab.Pankep).

\section{KESIMPULAN}

Berdasarkan hasil dan pembahasan penelitian ini, maka peneliti dapat menyimpulkan bahwa; (1) suatu pengelolaan sekolah/madrasah yang baik dengan peranan kepala sekolah/madrasah yang maksimal dan bertanggung jawab, akan berdampak terhadap keberhasilan madrasah dan akan terjamin kualitas pendidikan sesuai standar nasional pendidikan, (2) Kepemimpinan kepala madrasah menjadi tauladan bagi para guru terutama yang berkaitan dengan kedisiplinan yang menjadi sorotan warga masyarakat, (3) Kepala madrasah bertanggung jawab atas proses penyelenggaraan kegiatan pendidikan secara berintegritas dan profesional.

Rekomendasi yang dapat diberikan dari penelitian ini adalah sebagai berikut: (1) Kepala sekolah harus meningkatkan kompetensi manajerialnya dalam mengelola semua sumberdaya untuk memberikan layanan pendidikan yang berkualitas kepada masyarakat, (2) Kepala sekolah harus menjadi sosok tauladan tidak hanya bagi guru, juga kepada warga sekolah dan masyarakat, (3) Kepala Madrasah harus memiliki integritas yang tinggi dan profesional dalam menjalankan tugasnya.

\section{DAFTAR PUSTAKA}

Asmendri, A., Marsidin, S., Rusdinal, R., \& Mukhaiyar, M. (2018). An Analysis of Managerial Competence of the Madrasah Principals in Islamic Senior High School in Tanah Datar. Al-Ta Lim Journal, 25(1), 56-70.

Aguslani. (2019). Analisis Enam Kompetensi Pengawas Madrasah. Jurnal Balai Diklat Keagamaan Bandung. Vol.13(2) hal.220 -229. ISSN 2085-4005.

Dirjen PMPTK. (2009). Dimensi Kompetensi Supervisi Manajerial. Direktorat Jenderal Peningkatan Mutu Pendidik Dan Tenaga Kependidikan Departemen Pendidikan Nasional 2009.

Hariawan \& Eaqih, (2016). Daya Tarik Ponpes Yanmu nw Praya Sebagai Pilihan Masyarakat dalam Pendidikan Anak di Kab.LombokmTengah. Jurnal Paedagogy, 3(1), 10-18.

Hariawan, R., Ulfatur, N., Huda A. Y., M., \& Arifin, I. (2019). Contributions Management of Parenting and Education Program to Strengthen the Service Three Early Childhood Education Center. International Education Studies, 12(2), 100. https://doi.org/10.5539/ies.v122p100

Ibrohim, S, Djaelani, Juni S, (2016). Pelaksanaan Supervisi Manajerial Pengawas Sekolah 
Menengah Atas Swasta di Kota Banda Aceh, Departemen Pendidikan Nasional, No.7 Tahun 2010 Tentang tujuan suprvisi manajerial oleh Pengawas Sekolah/Madrasah..Retrieved from; Jurnal Administrasi Pendidikan Pascasarjana Universtas Syiah Kuala. Vol.4 (1), h.149. ISSN.2302-9156pp. 148-157

Imron. Purwanto \& Rohmadi, Y. (2021). Kompetensi Manajerial Kepala Madrasah dalam Mengembangkan Kinerja Tenaga Pendidik dan Tenaga Kependidikan. Jurnal Ilmiah Ekonomi Islam, 7(01), 350359. http://dx.doi.org/10.29040/jiei.v7i1.2228

Maranting, H, S, (2020).Peranan Pengawas Pendidikan Agama Islam dalam Meningkatkan Kualitas Gusu, Keputusan Menteri Negara Pendayagunaan Aparatur Negara No.118/1996 Retrieved form Jurnal Manajemen Pendidikan Islam, vol. 8(1). Dep. Agama RI.

Nursaid, N. (2020). The Leadership of Headmaster in Improving the Quality of Madrasa Education. Jurnal Pendidikan Islam, 6(1), 95108.

Peraturan Menteri Pendidikan Nasional Republik Indonesia Nomor 13 Tahun 2007 Tentang Standar Kepala Sekolah/Madrasah.

Peraturan Menteri Pendidikan dan Kebudayaan Republik Indonesia Nomor 37 Tahun 2018 Tentang Perubahan atas Peraturan Menteri Pendidikan dan Kebudayaan Nomor 24 Tahun 2016 Tentang Kompetensi Inti dan Kompetensi Dasar Pelajaran Pada Kurikulum 2013 Pada Pendidikan Dasar dan Pendidikan Menengah.

Kusuma, A.R. Hamengkubuwono, Ifnadi, Warlizasusi, J. (2020). Analisis Supervisi Klinis Pengawas Dalam Meningkatkan Sekolah DasarNegeri di Kecamatan Megang Sakti. Journal Improvemen, vol:7, h.104. No.1 Juni 2020.

Miles, M. B., Huberman, M. A., \& Saldana, J. (2014). Qualitatuve Data Analysis (3rd Ed.). California: SAGE Publication, Inc.

Imron, Purwanto \& Rohmadi. (2021). Kompetensi Manajerial Kepala Madrasah dalam Mengembangkan Kinerja Tenaga Pendidik \& Tenaga Kependidikan. Jurnal Ilmu Ekonomi Islam: 7(01),h. 350.

Peraturan Menteri PAN \& RB Nomor 21 Tahun 2010, Tentang Tugas Pokok Pengawas

Peraturan Menteri Negara Pendayagunaan Aparatur Negara dan Reformasi Birokrasi Nomor

21 Tahun 2010 Tentang Jabatan Fungsional Pengawas Sekolah dan Angka Kreditnya.

Peraturan Menteri Pendidikan dan Kebudayaan Republik Indonesia Nomor 143 Tahun 2014

Tentang Petunjuk Teknis Pelaksanaan Jabatan Fungsional Pengawas Sekolah dan Angka Kreditnya.

Peraturan Menteri Pendidikan Nasional Republik Indonesia Nomor 12 Tahun 2007 Tentang Standar Pengawas Sekolah/Madrasah.

Peraturan Menteri Pendidikan Dan Kebudayaan Republik Indonesia Nomor 37 Tahun 2018 Tentang Perubahan Atas Peraturan Menteri Pendidikan Dan Kebudayaan Nomor 24 Tahun 2016 Tentang Kompetensi Inti Dan Kompetensi Dasar Pelajaran Pada Kurikulum 2013 Pada Pendidikan Dasar Dan Pendidikan Menengah.

Peraturan Menteri Pendidikan Nasional Republik Indonesia Nomor 12 Tahun 2007 Tentang Standar Pengawas Sekolah/Madrasah.

Robbins, P. (2011). Political ecology: A critical introduction (Vol. 16). John Wiley \& Sons.

Sahertian, P.A. (2000). Konsep Dasar \& Tehnik Pendidikan (Jakarta; Rineka Cipta, 2000), h. 19

Taufik. (2019). Raker kepala sekolah \& pengawas ser-Kab.Pankep (Kasubag Perencanaan \& Data Dinas Kab.Pankep.

Wijaya. (2021). Supervisi Manajerial Kepala Madrasah Dalam Meningkatkan Kedisiplinan Guru Madrasah. h. 66.

Wijaya. (2021). Supervisi Manajerial Kepala Madrasah Dalam Meningkatkan Kedisiplinan Guru Madrasah. h. 69. 